Article

\title{
Freshwater-Saltwater Interactions in a Multilayer Coastal Aquifer (Ostia Antica Archaeological Park, Central ITALY)
}

\author{
Margherita Bonamico, Paola Tuccimei *, Lucia Mastrorillo (D) and Roberto Mazza \\ Dipartimento di Scienze, Università “Roma Tre”, 00146 Roma, Italy; bonamicomargherita@gmail.com (M.B.); \\ lucia.mastrorillo@uniroma3.it (L.M.); roberto.mazza@uniroma3.it (R.M.) \\ * Correspondence: paola.tuccimei@uniroma3.it
}

Citation: Bonamico, M.; Tuccimei, P.; Mastrorillo, L.; Mazza, R. FreshwaterSaltwater Interactions in a Multilayer Coastal Aquifer (Ostia Antica Archaeological Park, Central ITALY). Water 2021, 13, 1866. https://doi.org/ 10.3390/w13131866

Academic Editors: Evangelos Tziritis and Andreas Panagopoulos

Received: 1 June 2021

Accepted: 1 July 2021

Published: 4 July 2021

Publisher's Note: MDPI stays neutral with regard to jurisdictional claims in published maps and institutional affiliations.

Copyright: (c) 2021 by the authors. Licensee MDPI, Basel, Switzerland. This article is an open access article distributed under the terms and conditions of the Creative Commons Attribution (CC BY) license (https:/ / creativecommons.org/licenses/by/ $4.0 /)$.

\begin{abstract}
An integrated research approach consisting of hydrogeologic and geochemical methods was applied to a coastal aquifer in the Ostia Antica archaeological park, Roma, Italy, to describe freshwater-saltwater interactions. The archaeological park of Ostia Antica is located on the left bank of the Tevere River delta which developed on a morphologically depressed area. The water monitoring program included the installation of multiparametric probes in some wells inside the archaeological area, with continuous measurement of temperature, electrical conductivity, and water table level. Field surveys, water sampling, and major elements and bromide analyses were carried out on a seasonal basis in 2016. In order to understand the detailed stratigraphic setting of the area, three surface boreholes were accomplished. Two distinct circulations were identified during the dry season, with local interaction in the rainy period: an upper one within the archaeological cover, less saline and with recharge inland; and a deeper one in the alluvial materials of Tevere River, affected by salinization. Oxygen and carbon isotopic signature of calcite in the sediments extracted from the boreholes, along with major elements and $\mathrm{Br}$ concentration, allowed us to recognize the sources of salinity (mainly, local interaction with Roman salt pans and agricultural practices) and the processes of gas-water-rock interaction occurring in the area. All these inferences were confirmed and strengthened by PCA analysis of physicochemical data of groundwater.
\end{abstract}

Keywords: freshwater-saltwater interactions; multilayer coastal aquifer; hydro-geochemistry; Tevere River delta; Ostia Antica archaeological park

\section{Introduction}

Salinization of fresh groundwater is a global issue and a major threat to sustainable groundwater resources [1]. It is mainly caused by evaporite dissolution [2], fossil seawater [3] and seawater intrusion [4]. Seawater intrusion is defined as the mass transport of saline waters into zones previously occupied by fresher waters [5] due to natural processes or human activities.

Worldwide, aquifers in low-lying coastal areas are threatened by saltwater occurrence, as a result of small head gradients, high groundwater abstraction rates, and drain management of the landscape [6]. Urban and industrial development and the expansion of irrigated agriculture have led to a drastic increase in the exploitation of groundwater resources. The over-exploitation of coastal aquifers has caused a seawater intrusion and has seriously degraded groundwater quality [1]. In order to assess the influence of seawater on a coastal aquifer, it is essential to elucidate the source(s) of salinity and to understand the hydraulic and hydrogeochemical conditions [7].

In coastal environments, rivers are preferential way to lead seawater inland through salt-wedge intrusion [8]. Some authors [9] reported how anthropogenic land subsidence, land reclamation drainage system, and groundwater pumping in coastal areas of North Queensland, Australia, have an impact on dynamics of seawater intrusion in the phreatic aquifer. Another study on the salinization of a coastal aquifer in South Korea [10] showed 
that water hydrochemistry is controlled by several intermixed processes, such as seawater mixing, anthropogenic contamination, and water-rock interaction. A comprehensive review of groundwater salinization processes in coastal areas of the Mediterranean region was recently published [11].

Lately, a significant amount of literature has focused on subsurface water exchange between land and sea, both in coastal areas and marine environments. This issue was addressed using either physical approaches such as hydrogeological analysis, seepage meters, and geophysical methods, or employing chemical methods such as terrestrial water quality analysis, marine chemistry, and nutrients [12]. Modelling approaches were also applied [12]. Many papers were devoted to sub-seafloor freshened groundwater research and to application of the modern 3D shallow seismic technology to detect offshore freshened groundwater systems, for example in the Atlantic Ocean [13,14] and in the Baltic Sea [15-17].

No similar studies are available for the submerged Tevere River Delta (TRD) in central Italy, which is the area investigated in this work, and proximate offshore areas. Existing research made use of deep seismic technology to reconstruct the crustal structure and the complex geological settings of the Central Mediterranean Sea around the Italian Peninsula, e.g. ref. [18] or were focused on the reconstruction of the sedimentary succession of the emerged Tevere River Delta [19]. Furthermore, the coastal plain of the Tevere River is not among the hydrogeological complexes of the Tyrrhenian Sea with highest discharge. Most relevant water resources (in the order of some hundreds of $\mathrm{Mm}^{3}$ /year) are available for the Volturno Plain, Pontina Plain, Solofrana-Sarno Plains and Sele Plain [20].

This study focuses on the freshwater-saltwater interactions in a multilayer coastal aquifer of Roma, hosted in the Tevere River Delta depositional sequence. Recent studies [21] suggest that the Roman coastal aquifer reaches electrical conductivity (EC) values up to $5000 \mu \mathrm{S} / \mathrm{cm}$ and that groundwater salinization could be related to a combination of land use and historical development of the TRD, rather than to seawater. In the Roman coastal aquifer, EC shows a wide variability from area to area, due to agriculture practices which employ brackish water for irrigation and for the presence of the ancient salt pans [22] Moreover, the salinization of groundwater on the left bank of Tevere River could be related to the salt-wedge intrusion along the river course up to a distance of $8 \mathrm{~km}$ from the mouth [23] and to a lateral inflow of the river into the aquifer, due to different hydraulic heads and triggered by the drainage system [21].

Finally, in the dune part of the Roman coastal aquifer covered by Pinus pinea forest, the chemistry of groundwater is dependent on the barrier-effect accomplished by canopies to the wind-transported sea salt aerosol, periodically discharged into the aquifer by rainfalls [24]. The deposition of sea salt aerosol mainly occurs in spring and summer when the winds blow from the west at speeds above $4 \mathrm{~m} / \mathrm{s}$ [25].

The goal of this paper is the study of the groundwater of the Ostia Antica archaeological park, which is a part of the vast Roman coastal aquifer (Roma, central Italy) using an integrated hydrogeological and hydrogeochemical approach. In particular, we aim to deepen the knowledge of freshwater-saltwater interactions and identify the sources of local salinity. Gas-water-rock interaction processes were considered to justify groundwater composition and understand the mixing dynamics of the aquifer with the Tevere River and the marine water.

\section{Study Area}

The study area, located SW of Roma (Italy), is bounded to the S by the Castel Fusano Reserve, to the NNE by the Tevere River, and to the E by the Tyrrhenian Sea. It includes the archaeological park of Ostia Antica, with an extension of $1.5 \mathrm{~km}^{2}$, and the Castle of Julius II to the NNE (Figure 1). 


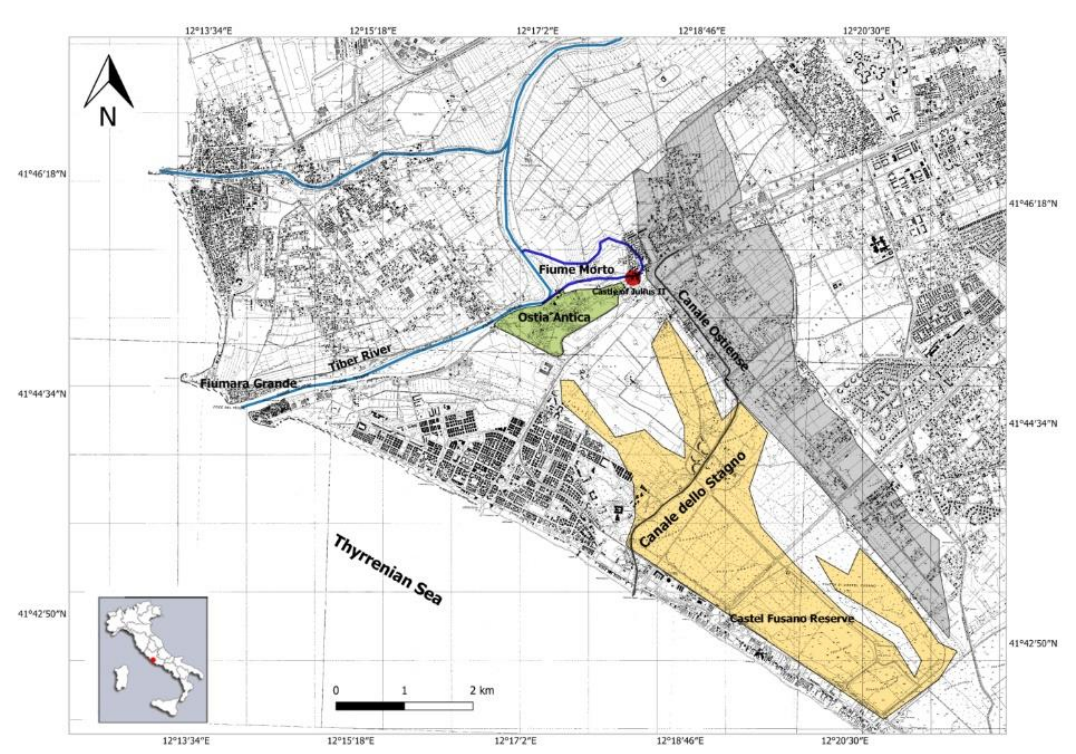

(a)

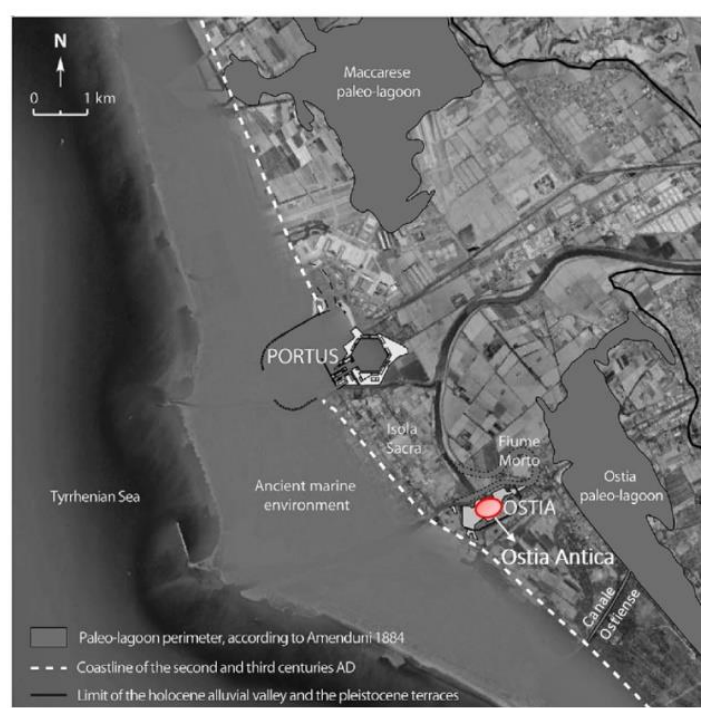

(b)

Figure 1. (a) Study area features: Ostia Antica archaeological park (green area), the old river meander called "Fiume Morto" with the Castle of Julius II (red dot), Tevere River (blue line), reclamation channels (thick black line), Roman salt pans (grey area), and the Castel Fusano reserve (yellow area). (b) Localization of the Ostia Antica archaeological park and the old meander called "Fiume Morto" with respect to paleo-lagoon areas of Ostia and Maccarese (modified from [26]).

The area, with an elevation of approximately 2-4 $\mathrm{m}$ a.s.l., has a typically Mediterranean climate with a warm and dry period from mid-May to mid-August. Meteorological data (period 1971-2000) show that the average annual rainfall is $741 \mathrm{~mm}$, distributed over 72 days, with a minimum in summer and a maximum in autumn. The month of January has the coldest temperatures with an average of $8.6^{\circ} \mathrm{C}$, while August is the warmest month with an average temperature of $24.1^{\circ} \mathrm{C}$ [27].

The study site develops on the left bank of the Tevere River on a morphologically flat environment. The general evolution of the TRD after the Last Glacial Maximum was mainly driven by the post-glacial uplift of the sea level (between 18,000 and 6000 years ago), and by the variations in river sediment discharge in the last 6000 years [19]. The shoreline progressively moved away from the coastal basins that developed into brackish ponds, currently reclaimed. The basin located on the left bank of the river, called Ostia paleo-lagoon, developed behind the current Ostia Antica archaeological park, extending to the $S$ for at least $6 \mathrm{~km}$, and communicating with the sea through the present Canale dello Stagno channel (Figure 1a). The basin of Ostia and the one located on the right bank, the basin of Maccarese (Figure 1b) have been exploited as salt pans from Roman to more recent times.

Different phases of progradation and erosion of the delta alternated. During the 15th century, coinciding with the four historically documented major floods of the Tevere River (AD 1530, 1557, 1598, and 1606), a rapid progradation of TRD took place. During the disastrous flood of 1557 AD, the Tevere River changed course, leaving a meander in the area of Ostia Antica, which later became a lake and then an isolated marshy area, now known as "Fiume Morto" (Figure 1). Towards the end of the 19th century, a law on reclamation was approved and an important drainage system was built [28]. The reclamation system consists of a network of channels that collect rainwater and discharge groundwater from a pumping station into the sea, with the function of preventing the flooding of low ground and keeping groundwater below the ground surface.

The inland delta consists of transitional mid-littoral deposits, such as sands, siltysands, and clays interbedded with gravels, with volcanoclastic grains from the erosion of Colli Albani volcanic rocks. They were deposited during several Pleistocene transgressive cycles, with an overall thickness of $50 \mathrm{~m}$. 
The seaside area of the delta includes dune cordons, grown parallel to the coast during the progradation stages of the last 2500 years. It is characterized by Holocene deposits, mostly composed of coastal and eolian sands, with a lateral transition to the 10-30 m thick alluvial sediments of Tevere River [29].

A fresh-brackish water multilayer aquifer is hosted in the Pleistocene and Holocene sediments of the TRD left bank. The Plio-Pliestocene clayey bedrock acts as a regional basal aquiclude (Figure 2). Throughout the aquifer, the preferential direction of groundwater flow is towards the sea, with the exception of the area surrounding Ostia Antica, where the reclamation pumping system controls the local base level of groundwater circulation. The main direction of groundwater flow in the archaeological park is from $\mathrm{E}$ to $\mathrm{W}$, towards an area of induced lowering of the water table up to $-2 \mathrm{~m}$ a.s.l. [21,30,31].

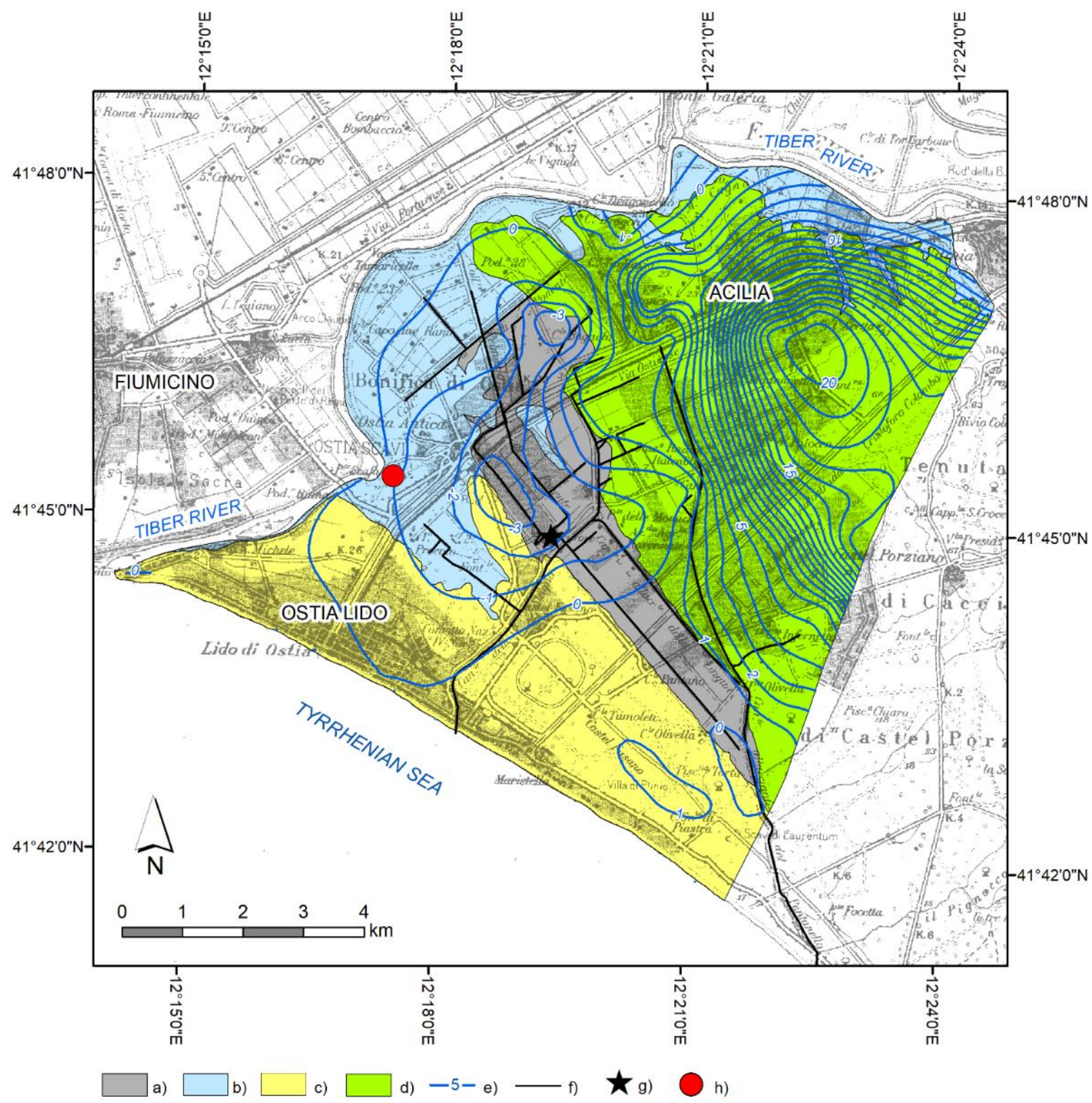

Figure 2. Hydrogeological settings of the left bank of the Tevere River Delta. Legend: (a) swamp deposits HOLOCENE; (b) sandy, silty and clayey alluvial deposits HOLOCENE; (c) sandy beach deposits HOLOCENE; (d) heterogeneous clastic deposits (sandy-silt and clay deposits interbedded with gravels) PLEISTOCENE; (e) groundwater contour lines (1 $\mathrm{m}$ interval); (f) reclamation channels; (g) Ostia pumping station; (h) study area (modified from [32]). 


\section{Material and Methods}

Groundwater was collected from wells located inside the archaeological area (P1, P2, P8, P9, and P10) near the old meander (P6 and P7) and in the castle of Julius II (P4); the Tevere River was sampled near the archaeological park (P5) (Figure 3a,b).

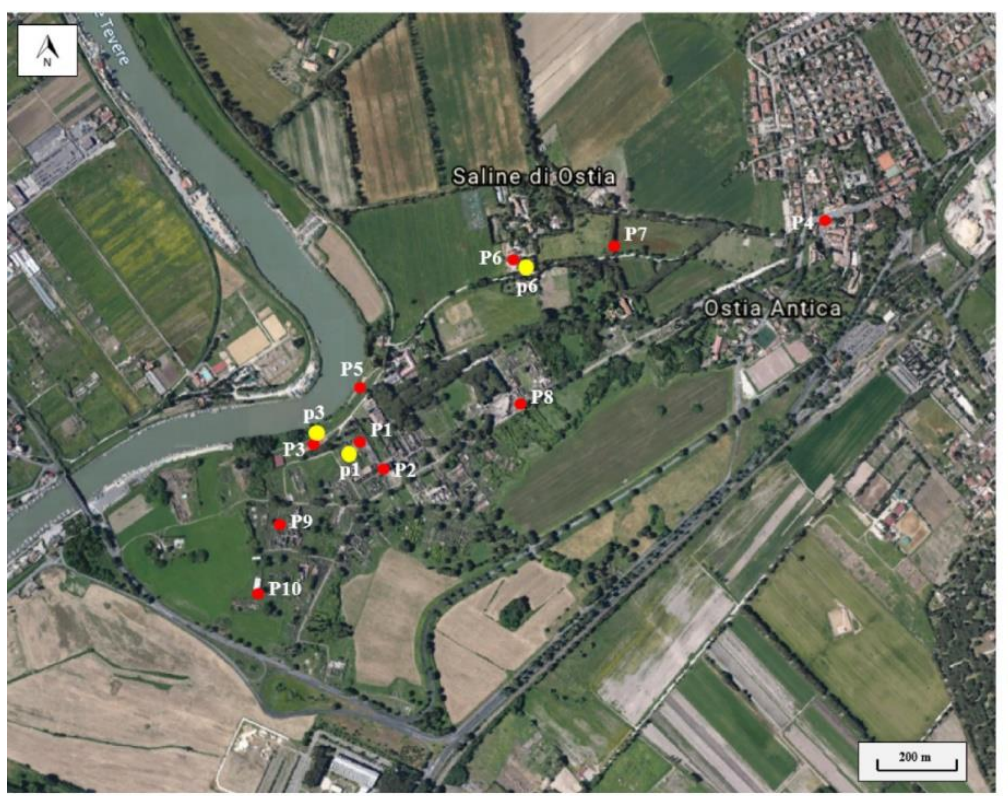

(a)

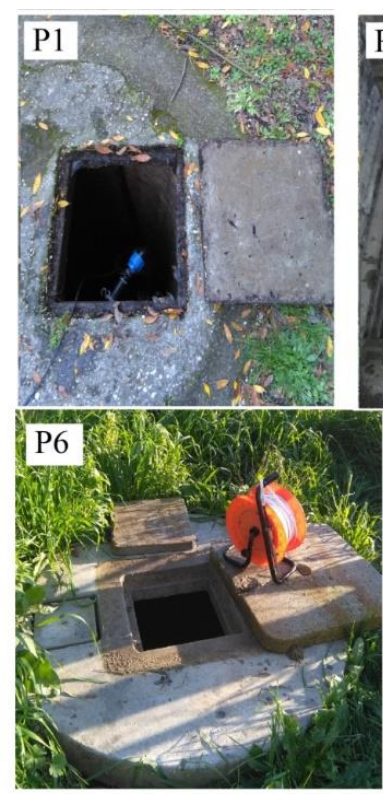

(b)

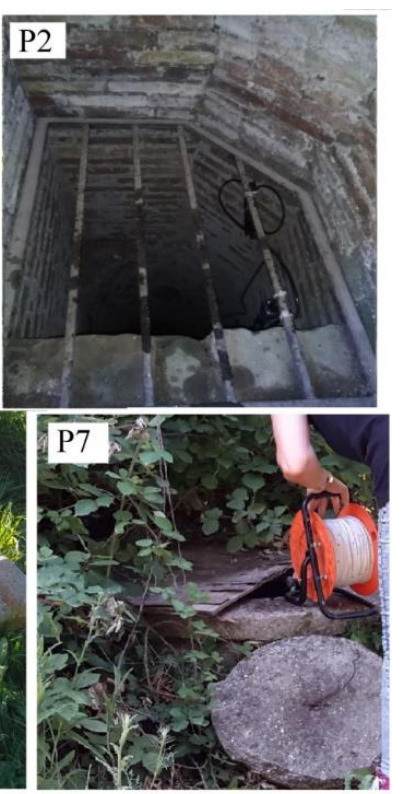

Figure 3. (a) Location of sampling wells (red points) and drillings (yellow points). (b) Some monitored wells: P1, P2, P6, and P7. For geographic coordinates in Figure 3a, the reader is referred to Figures 1 and 2.

The field surveys were carried out on a seasonal basis in the months of April, June, October, and December of 2016 in order to obtain representative data of the dry and wet seasons. Periodical field surveys consisted of manually measuring the static level, $\mathrm{pH}$, temperature, and electrical conductivity of groundwater and taking water samples. Groundwater level and electrical conductivity (EC) were monitored continuously since 2014 at 6 h intervals at wells P1, P2, and P3. The 2016 rainfall data measured by the Ostia pluviometric station near the study area were also acquired.

It is worth noting that the well bottoms are placed below the sea level, and vary from a maximum of about $-2.5 \mathrm{~m}$ a.s.l. in $\mathrm{P} 4$ and a minimum of $-0.17 \mathrm{~m}$ a.s.l. for well P10.

Temperature, $\mathrm{pH}$, and EC were measured using a portable multiparameter probe. Samples were collected and stored in clean PET bottles, rinsed thrice with native water, before sampling. An aliquot for cation analysis was filtered $(0.45 \mu \mathrm{m}$ Millipore filters $)$ and acidified with concentrated $\mathrm{HNO}_{3}(68 \%)$ before storage. In order to avoid chemical reactions, samples were stored at a temperature of $4{ }^{\circ} \mathrm{C}$.

Alkalinity was measured in the field by titration with $0.02 \mathrm{~N} \mathrm{HCl}, \mathrm{Ca}^{2+}$ and $\mathrm{Mg}^{2+}$ were determined using the EDTA titration method, $\mathrm{Na}^{+}$and $\mathrm{K}^{+}$by flame emission photometric method, $\mathrm{Cl}^{-}$and $\mathrm{Br}^{-}$by potentiometric methods with ion-selective electrodes, and $\mathrm{SO}_{4}{ }^{2-}$ by a colorimetric method using turbidimetric techniques [33]. The precision of photometric, potentiometric, and spectrometric measurements was always better than $0.5 \%$. The accuracy of measurements, checked against standard reference material was found to be generally within $4 \%$.

In June 2016 three 3-5 m deep drillings (p1, p3, and p6) were performed next to wells P1, P3, and P6, employing a two-man auger Stihl BT 360 motor drill (Figure 3a). A small amount of sediment samples collected along the three drillings were dried at $100{ }^{\circ} \mathrm{C}$ and made to react with $1 \mathrm{~N} \mathrm{HCl}$ to check the presence of calcite cement observed in the sedimentary sequence. 
Saturation index for calcite of groundwater was modelled with PHREEQC for Windows (version 2.18.00), a hydrogeochemical transport software developed by [34].

Base EXchange index (BEX), sensu [35], was calculated for groundwater average composition, as reported below:

$$
\left[\mathrm{Cl}^{-}-\left(\mathrm{Na}^{+}+\mathrm{K}^{+}\right)\right] / \mathrm{Cl}^{-}
$$

where ion concentration is expressed in meq/L.

Carbon and oxygen isotope composition of calcite cements were determined at the IGAG, CNR laboratory (Montelibretti, Roma, Italy) using a Mat 252V mass spectrometer, manufactured by Finnigan (Bremen, Germany) according to the procedure described in [36].

OriginPro 9.0 (ADALTA) software was used to apply principal component analysis (PCA) to water chemistry data in order to transform a large set of variables into a smaller one that still contains most of the information and investigate the main geochemical trends. Eleven variables (chemical parameters) were chosen for the multivariate analysis: $\mathrm{HCO}_{3}$, $\mathrm{Cl}, \mathrm{SO}_{4}, \mathrm{Ca}, \mathrm{Mg}, \mathrm{Na}, \mathrm{K}, \mathrm{Br}$, Water table elevation, $\mathrm{Br} / \mathrm{Cl}$, and $\mathrm{EC}$.

\section{Results}

\subsection{Groundwater Data}

Groundwater physicochemical data are shown in Table S1 (Supplementary Material). Lowest piezometric levels were recorded in October 2016 and highest in December 2016; in all survey campaigns the minimum static level was found in wells P6 and P4, at $-1 /-1.4 \mathrm{~m}$ a.s.l. and $-1.3 \mathrm{~m}$ a.s.l., respectively. Wells P6 and P7, located outside the archaeological area, generally had a static level below sea level. Tevere River had a constant level of $+0.01 \mathrm{~m}$ a.s.l. in April, June, and October 2016, while in December 2016 the level of the river was lower ( $-0.31 \mathrm{~m}$ a.s.l.). Finally, wells P2, P8, P9, and P10 showed groundwater table fluctuations between -0.5 and $+0.4 \mathrm{~m}$ a.s.l.

The average temperature of groundwater was $16.8^{\circ} \mathrm{C}$, while the temperature of the Tevere River ranged from 15.1 (April 2016) to $19.3^{\circ} \mathrm{C}$ (June 2016). Groundwater and Tevere River generally showed neutral and slightly basic $\mathrm{pH}$ values, except for the June survey when waters were slightly acidic (6.6 on average). EC values range from 404 (well P10 in December 2016) to 4820 (well P6 in December 2016) $\mu \mathrm{S} / \mathrm{cm}$. Two main groups of groundwater may be recognized: P2, P3, P4, P8, P9, and P10 with EC from 400 to $1450 \mu \mathrm{s} / \mathrm{cm}$, and P1, P6, and P7 with EC between 1350 and $4800 \mu \mathrm{S} / \mathrm{cm}$.

Figure 4 shows the static levels recorded in continuum in wells P1, P2, and P3 and the daily rainfall value measured in Figure $4 \mathrm{a}$. In Figure $4 \mathrm{~b}$ the EC values recorded in P1, $\mathrm{P} 2$, and P3 were reported. It can be observed that the water table of P1 ranged between approximately $-0.7 \mathrm{~m}$ a.s.l. in summer/autumn and $+0.3 \mathrm{~m}$ a.s.l. in winter; well $\mathrm{P} 2$ had values on average higher than P1 with a static level fluctuation between $-0.55 \mathrm{~m}$ a.s.l. (in September-October 2016) and about +0.3 a.s.l. (in December 2016). Well P3 showed a maximum static level of $+0.4 \mathrm{~m}$ a.s.l in December 2016 and a minimum value of $-0.4 \mathrm{~m}$ a.s.l. in September-October 2016.

\subsection{Stratigraphy}

The stratigraphic sequence unveiled by the drillings consists of 2-2.3 $\mathrm{m}$ of anthropic backfill (pozzolanaceous and/or alluvial material with layers filled with calcite cements), and sandy or silty-clayey deposits up to a depth of about $-3.7 \mathrm{~m}$ below ground level, where a grey clayey layer was identified. The water table was crossed by $\mathrm{p} 6$ drilling at $-1 \mathrm{~m}$ a.s.l ( $-3.65 \mathrm{~m}$ below ground level). All sediment samples taken at different depths from the three drillings reacted with $\mathrm{HCl}$, confirming the presence of calcite cement, very frequent in alluvial and pozzolanic materials. Oxygen and carbon isotopic compositions of calcite cements in the sedimentary sequence of $\mathrm{p} 1$ and $\mathrm{p} 6$ drillings are different. Calcite in $\mathrm{p} 1$ is characterized by $\delta^{18} \mathrm{O}$ and $\delta^{13} \mathrm{C}$ values of -5.06 and $-5.50 \%$ (VPDB), respectively, 
whereas p6 sample, has a more negative isotopic signature, specifically of -8.96 and $-12.88 \%$ (VPDB) for oxygen and carbon.

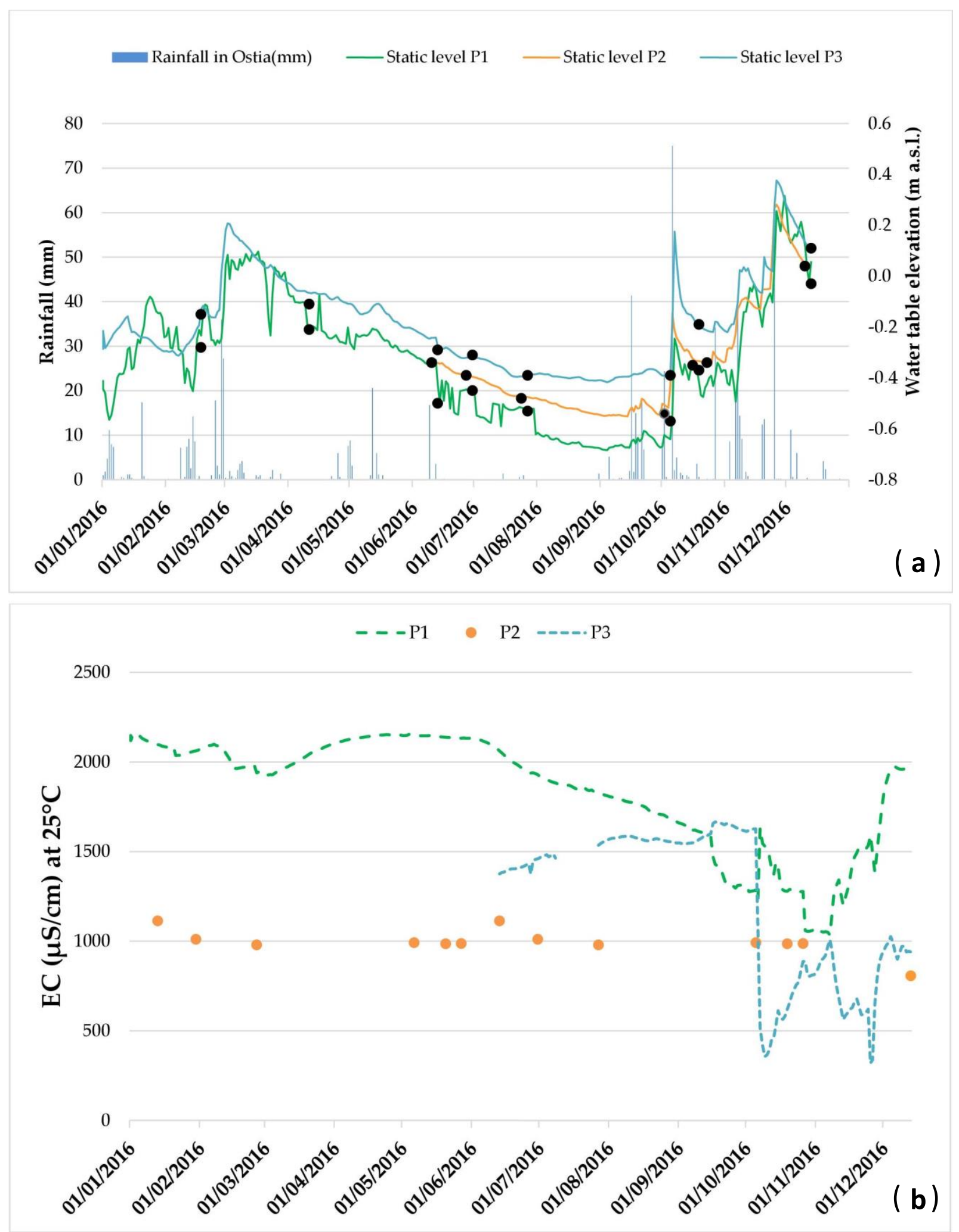

Figure 4. (a) Rainfall amount and water table level recorded at wells P1, P2, and P3 during the year 2016. Manual water level measurements (black dots) are superimposed on the continuous water level recorded at wells P1, P2, and P3. (b) Electrical conductivity (EC) of wells P1, P2 (discontinuous manual measurements), and P3 during the year 2016. 


\subsection{Hydrochemistry}

Major ions and $\mathrm{Br}^{-}$concentrations of groundwater are reported in Table S2 (Supplementary Material). Main cations and anions abundances are shown in Figure 5 to recognize the hydrochemical facies. Groundwater from wells P2, P4, and P9 are alkaline bicarbonate, with data points located at the boundary with the calcium-magnesium bicarbonate facies, therefore rich in $\mathrm{Ca}^{2+}$ (and less in $\mathrm{Mg}^{2+}$ ), as well as in alkalis (Figure 5). Groundwater from P3, P8, and P10 belongs to the calcium-magnesium bicarbonate facies, enriched in calcium but also in alkalis (mainly $\mathrm{Na}^{+}$). All these samples belong to the shallower circulation.

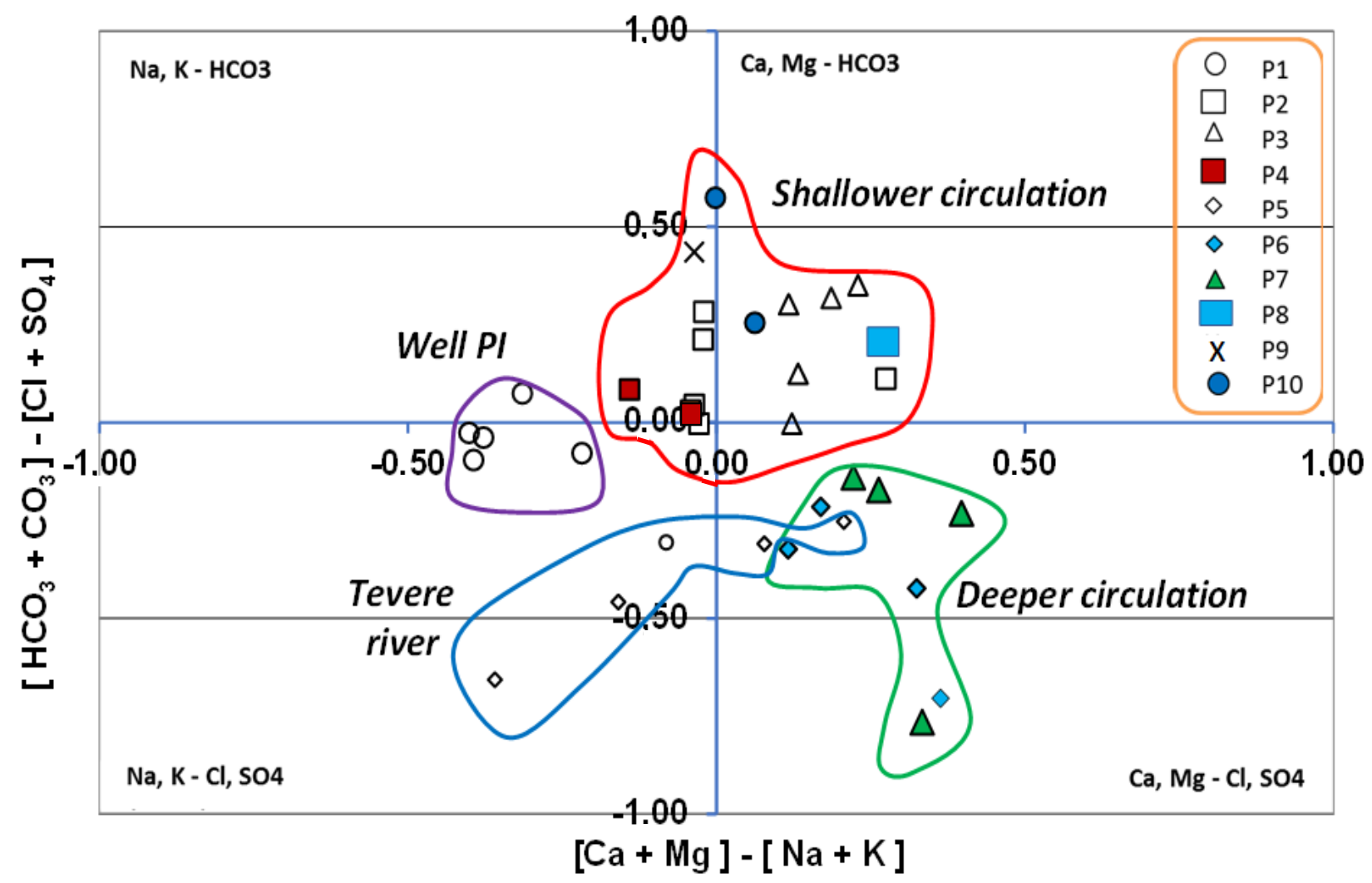

Figure 5. Chada diagram with composition of groundwater sampled during the year 2016.

P6 and P7 groundwater falls in the calcium-magnesium chloride-sulphate field of Figure 5 and are referred to the deeper circulation. The Tevere River (P5) is a mixing between alkaline chloride-sulphate and calcium-magnesium chloride-sulphate waters. Finally, $\mathrm{P} 1$ is an alkaline chloride-sulphate water, with an enrichment in bicarbonates and $\mathrm{Mg}^{2+}$. Average $\mathrm{Cl} / \mathrm{Br}$ (molar) ratio of the wells P2, P3, P8, P9, and P10 is 180; Tevere River (P5) and P1 are characterized by ratios of 260 and 185, respectively; wells P6 and P7 have an average $\mathrm{Cl} / \mathrm{Br}$ (molar) ratio of 400 .

These considerations are supported by the PCA analysis, as discussed in the following section.

\section{Discussion}

\subsection{Groundwater Data}

Interpretation of the groundwater levels data suggests the presence of two possible circulations. An upper circulation was identified in the archaeological park and a lower one in the abandoned meander of the Tevere River area; the two circulations have the same flow direction (WSW-ENE) and base level (the Primary Collector channel, at $-2 \mathrm{~m}$ a.s.l), but are characterized by different values of salt concentration (EC values). The shallowest aquifer, hosted in the pozzolanic and sandy materials in the archaeological area, displays 
the highest water table elevation (0.3-0.2 $\mathrm{m}$ a.s.l.). The deepest circulation, flowing in the alluvial deposits, has the highest groundwater level near the Tevere River bank, between -0.1 and $-0.6 \mathrm{~m}$ a.s.l. The aquiclude interposed between the two circulations probably consists of a low permeability sandy clayey layer. This layer was probably intersected by two out of three drillings from about -1.00 to $-1.40 \mathrm{~m}$ a.s.l.

In proximity of well $\mathrm{P} 1$ the two circulations seem to be hydraulically connected during the rainy period (in December 2016), when the levels of the water table correspond, while they are well distinguished during the dry season (in October 2016). This is confirmed by the physicochemical analyses of groundwater from well P1 which displays a constant composition throughout the year, compared with other samples with medium-high EC values whose EC and hydrochemical facies change greatly depending on the season. No information is available on the lateral continuity of the deepest circulation, so it is not possible to predict if it is present below the shallowest one. Current hydrogeochemical data seem to suggest that the two circulations are not completely isolated during the dry season when groundwater static levels are different.

The coastal aquifer is recharged mainly in autumn and winter when rainfalls are concentrated (Figure 4a), as shown by the sudden rise of piezometric levels in all monitoring points (P1, P2, and P3). Water-table fluctuations are about $1 \mathrm{~m}$ between the dry season and the rainy one.

The rise of groundwater levels recorded in October-December 2016 in monitoring wells P1, P2, and P3 is directly correlated with a general decrease in the concentration of dissolved salts. In the period January-March 2016 when rainfalls were modest, only a slight decrease in EC values was measured for P1 and P3 groundwater, with values of approximately $1500-2000 \mu \mathrm{S} / \mathrm{cm}$. Finally, no continuous record of EC values was available for well P2, but using existing discontinuous data it can be observed that EC values ranged between 800 and $1110 \mu \mathrm{S} / \mathrm{cm}$ (Figure 4 b).

An inverse correlation between EC and groundwater levels was observed in the three monitored wells, where a relative increase in groundwater level corresponded to a decrease in water salinity. This is particularly evident for well P1 where the abundant rainfalls of October 2016 produced an increase of about $0.5 \mathrm{~m}$ in the piezometric level and a decrease in EC values from 1620 to $1000 \mu \mathrm{S} / \mathrm{cm}$ (Figure 4).

Another correlation can be underlined between EC values and well bottom elevations. Groundwater with higher average EC values $(1350-4800 \mu \mathrm{S} / \mathrm{cm})$ were sampled from wells P1, P6, and P7 whose bottom depth is lower than $-1 \mathrm{~m}$ a.s.l., while samples with average lower EC values (400-1450 $\mu \mathrm{S} / \mathrm{cm}$ ) were collected from wells P2, P3, P8, P9, and P10 with a depth higher than $-1 \mathrm{~m}$ a.s.l. It is worth noting that P6 and P7 wells are located near the abandoned meander of Tevere River and are linked with the deepest circulation, while the second group of wells are placed in the archaeological park where the shallowest circulation has been identified. Finally, P1 in the archeologic park represents the connection between the two circulations in the rainy period.

Groundwater average concentration of major elements resulting from the four surveys and average composition of sea water are plotted on the Schoeller diagrams, where relative ratios among ions are displayed allowing a direct comparison of waters' chemical composition (Figure 6a,b).

Samples from wells P2, P3, P4, P8, P9, and P10 (Figure 6a) are enriched in bicarbonates, in alkalis and in calcium. In particular, bicarbonate and alkalis are the dominant ions in $\mathrm{P} 2$, $\mathrm{P} 4$, and $\mathrm{P} 9$ waters, with high $\mathrm{Ca} / \mathrm{Mg}$ and $\mathrm{Cl} / \mathrm{SO}_{4}$ ratios (with the exception of well P4). P3, P8, and P10 are enriched in bicarbonates and calcium, with alkalis concentration comparable to that of calcium. The $\mathrm{Cl} / \mathrm{SO}_{4}$ ratio distinguishes between $\mathrm{P} 8$ and $\mathrm{P} 10$ groundwater on one side and P3 on the other. Chlorides are the dominant ion in the former wells, while sulphates are enriched in the latter one. None of the waters under investigation have sections of the curve equivalent to those of sea water. Finally, P1 groundwater is characterized by a low $\mathrm{Ca} / \mathrm{Mg}$ ratio, whereas the Tevere River (P5) water is relatively enriched in calcium compared with magnesium and in chlorides (Figure 6b). 


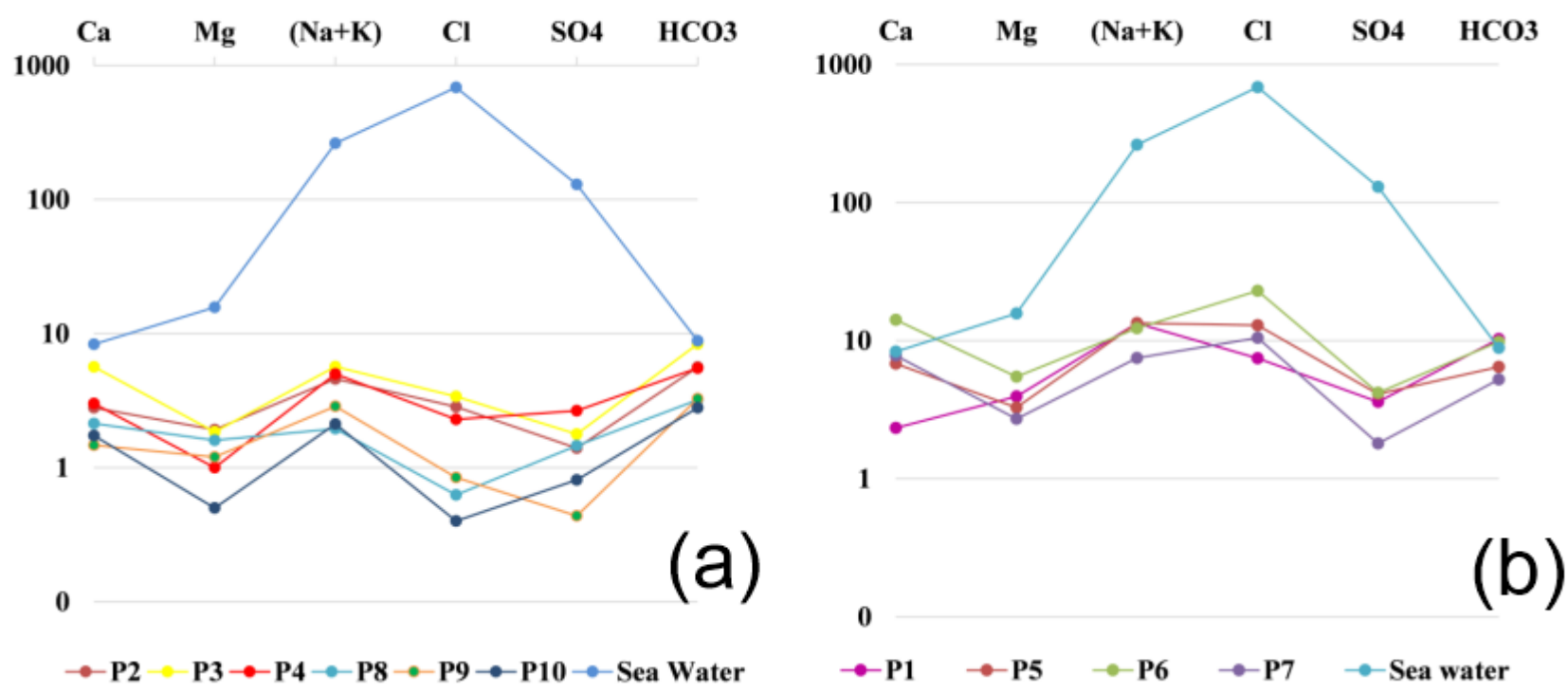

Figure 6. Schoeller diagrams with major elements ratios of groundwater (mg/L) from wells P2, P3, P4, P8, P9, and P10 (a) and P1, P5, P6, and P7 (b). Sea water composition is reported to better evaluate freshwater-saltwater interactions.

\subsection{Water-Rock Interaction}

Calcium bicarbonate groundwater prevails in the archaeological park, characterizing wells P3, P8, and P10. Pozzolanic materials outcropping in the area contains minerals deriving from the erosion of Colli Albani volcano products. Groundwater produces leaching and incongruent dissolution of leucite and pyroxene, very abundant in these deposits, with release of soluble cations and formation of alteration minerals such as zeolites or clay minerals [37]. Possible reactions affecting leucite and diopside, which justify groundwater composition, are reported below:

$2 \mathrm{KAlSi}_{2} \mathrm{O}_{6}$ (leucite) $+2 \mathrm{H}_{2} \mathrm{CO}_{3}+\mathrm{H}_{2} \mathrm{O} \rightarrow 2 \mathrm{~K}^{+}+2 \mathrm{HCO}_{3}{ }^{-}+2 \mathrm{SiO}_{2}+\mathrm{Al}_{2} \mathrm{Si}_{2} \mathrm{O}_{5}(\mathrm{OH})_{4}$ (caolinite)

$\mathrm{CaMgSi}_{2} \mathrm{O}_{6}$ (diopside) $+4 \mathrm{CO}_{2}+6 \mathrm{H}_{2} \mathrm{O} \rightarrow \mathrm{Ca}^{2+}+\mathrm{Mg}^{2+}+2 \mathrm{H}_{4} \mathrm{SiO}_{4}+4 \mathrm{HCO}_{3}{ }^{-}$

Alkaline bicarbonate groundwater of wells $\mathrm{P} 2, \mathrm{P} 4$, and $\mathrm{P} 9$ are linked to the presence of dissolved $\mathrm{CO}_{2}$ (enrichment in bicarbonates) and to the incongruent dissolution and cationic exchange phenomena (enrichment in alkalis). Negatively charged surfaces of clay minerals, very abundant in alluvial and delta environments, may adsorb and exchange cations, according to reactions such as:

$$
\mathrm{Ca}^{2+}+2 \mathrm{Na}-\mathrm{X}_{2} \leftrightarrow \mathrm{Ca}-\mathrm{X}_{2}+2 \mathrm{Na}^{+}
$$

when fresh and/or recharge water rich in calcium interacts with minerals which had previously adsorbed sodium from marine waters. This interaction produces the release of sodium from the minerals and the simultaneous absorption of calcium onto the mineral surface, joined to a dilution of chlorides concentration by fresher water. Alkaline bicarbonate waters are the result of this process, but could also be related to a local mixing between groundwater and Tevere River waters, where a wind-induced salt-wedge intrusion in the river mouth produces EC values up to $2400 \mu \mathrm{S} / \mathrm{cm}$ [23].

These phenomena could also be invoked to justify the composition of alkaline chloridesulphate water of the Tevere River and groundwater from well P1. This well is located in a morphologically depressed area located in proximity of the river at $-2 /-3 \mathrm{~m}$ a.s.l., where the river could locally infiltrate into the ground, recharging the aquifer. In addition to that, groundwater from well P1 is characterized by a strong depletion in calcium (Figure 6b), which is compatible with the precipitation of calcium carbonate, as shown by calcite minerals in the stratigraphic column. 
Calcium chloride-sulphate composition characterizes groundwater from wells P6 and P7. This composition could be due to a cationic exchange reaction, such as that reported below:

$$
\mathrm{Na}^{+}+\frac{1}{2} \mathrm{Ca}-\mathrm{X}_{2} \leftrightarrow \mathrm{Na}-\mathrm{X}+\frac{1}{2} \mathrm{Ca}^{2+}
$$

An input of salt water into the aquifer generates the release of calcium and the adsorption of sodium on the mineral surfaces, with a contemporaneous enrichment of groundwater with chlorides. The source of salts could be the ancient salt pans of Ostia, near the abandoned meander; actually, P6 and P7 water are characterized by high values of EC, respectively, up to 4800 and $2600 \mu \mathrm{S} / \mathrm{cm}$. Finally, irrigation of the fields for agricultural practices could introduce salt water into the aquifer.

\subsection{Sources of Salinity}

In order to classify groundwater and identify the sources of salinity, we employed the $\mathrm{Cl} / \mathrm{Br}$ ratio [38], the BEX index (Table S3, Supplementary Material), sensu [35], and the chloride content of groundwater.

First of all, it is possible to plot $\mathrm{EC}$ values versus $\mathrm{Cl} / \mathrm{Br}$ ratios (Figure 7). P6 and P7 groundwater is characterized by high $\mathrm{EC}$ and $\mathrm{Cl} / \mathrm{Br}$ ratios, where chlorides are abundant compared with bromides and the total ion contents. $\mathrm{Cl} / \mathrm{Br}$ ratios of wells $\mathrm{P} 6$ and P7 approach more than other samples the value of sea water, according to the presence of the ancient salt pans and the anthropogenic effect due to agricultural practice (see field $5 \mathrm{a}$ in Figure 7). Moreover, $\mathrm{P} 5$ shows intermediate $\mathrm{EC}$ and high, but extremely variable, $\mathrm{Cl} / \mathrm{Br}$ ratio. P1 groundwater, with EC comparable to that of the Tevere River, stands out for lower $\mathrm{Cl} / \mathrm{Br}$ ratios, along a hypothetical mixing line between the shallowest and the deepest circulations. Finally, wells P2, P3, P8, P9, and P10 exhibit low EC and variable $\mathrm{Cl} / \mathrm{Br}$ ratios; they are plotted adjacent to the field of "recharge in inland areas" (field $2 b$ in Figure 7).

Secondly, the BEX index of groundwater, sensu [35], was used to elucidate salinization phenomena (Table S3). This index indicates whether an aquifer was affected mainly by salinization or freshening phenomena; negative values of the BEX index were calculated for wells P1, P2, P3, P4, P8, P9, and P10, indicating a relative abundance of alkalis compared with chlorides, justified by a prevalent freshening and meteoric recharge of the aquifer, in agreement with $\mathrm{Cl} / \mathrm{Br}$ suggestion. On the contrary, $\mathrm{BEX}$ index is positive for wells $\mathrm{P} 6$ and P7 and for the Tevere River (P5), demonstrating the input of salt water into the aquifer, as confirmed by high values of $\mathrm{EC}$ and $\mathrm{Cl} / \mathrm{Br}$ ratio.

\subsection{Precipitation of $\mathrm{CaCO}_{3}$ from the Sampled Water}

Average saturation index for calcite of wells P1, P5, P6, P7, and P10 was positive (Table S3), indicating that groundwater composition is compatible with calcite cements permeating the sediments extracted from the drillings, while moderately negative values of wells P2 and P3 suggest a minor tendency to dissolve the mineral. 


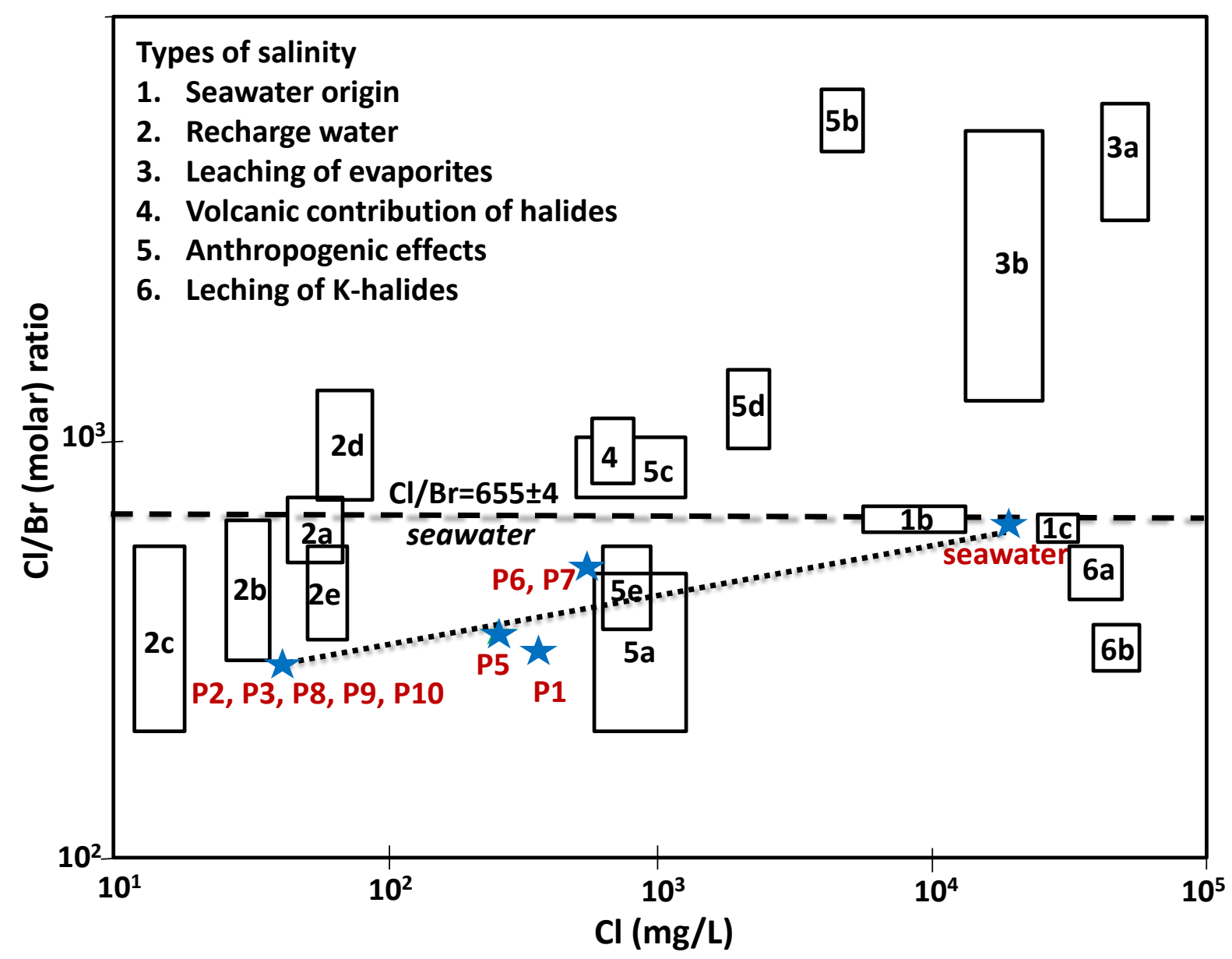

Figure 7. $\mathrm{Cl} / \mathrm{Br}$ (molar) ratio versus $\mathrm{Cl}$ concentration of groundwater in the Ostia Antica area (Roma, central Italy) plotted over the salinity classification fields set from 24 selected aquifers of Spain and Portugal (modified from [39]). Stars stand for the average composition of well from the 2016 survey. 1b—seawater intrusion; $1 \mathrm{c}$-seawater brines; 2a-recharge in coastal areas; $2 \mathrm{~b}$-recharge in inland areas; $2 \mathrm{c}$-recharge in high altitude/continental areas; $2 \mathrm{~d}$-recharge in coastal arid climate; $2 \mathrm{e}$-recharge in coastal polluted areas; $3 \mathrm{a}$-leaching of natural halite; $3 \mathrm{~b}$-leaching of gypsum containing halite; 4 -volcanic contribution of halides; $5 a$-agricultural pollution; $5 b$-leaching of industrial halite; $5 c$-leaching of garbage and solid water; $5 \mathrm{~d}$ - urban wastewater; $5 \mathrm{e}$ - septic waste; $6 \mathrm{a}$-leaching of carnalite; $6 \mathrm{~b}$-leaching of sylvite.

Since the occurrence of carbonate cement in the sedimentary sequence could provide information on the sources of carbon dioxide dissolved in groundwater, carbon ad oxygen isotopic analyses were carried out on calcite samples from drillings p1 and p6, located in proximity of wells $\mathrm{P} 1$ and $\mathrm{P} 6$, respectively (see Figure 3 for location). The isotopic signature of the two samples is plotted over a $\delta^{18} \mathrm{O}$ vs. $\delta^{13} \mathrm{C}$ diagram, where the composition of other carbonates (speleothems, travertines, and calcite encrustations) in the Roma area (Italy) are reported for comparison (Figure 8) [40-42]. The cement in $\mathrm{p} 1$ sequence, characterized by a $\delta^{13} \mathrm{C}$ of $-5.5 \%$ and $\delta^{18} \mathrm{O}$ of $-5.06 \%$ VPDB, falls very close to speleothems formed in artificial caves excavated in ignimbrites from the Colli Albani volcano, such as in a cellar in Ariccia town or in the "Acqua Vergine" and "Antonianiano" aqueducts in Roma [42]. This finding is sound because pozzolanic materials were largely used in the construction activities of ancient Romans and are abundantly present in the archaeological sequence of Ostia Antica park. Moreover, the carbon composition of $\mathrm{p} 1$ calcite corresponds to that of other carbonates in artificial conduits developed in the ignimbrites of Colli Albani volcano (emissary of Castiglione crater and "Anagnina" mushroom farm) [43] and in the pre-Roman remains of the ancient Portuense road at Ponte Galeria, where deep-seated fluids rich in $\mathrm{CO}_{2}$ upsurged, forming pools in the valley floor and depositing carbonate layers, a few 
kilometres NE of the road [40]. Such fluids continued to deposit calcite in the Middle Age and very scarcely today, with an isotopic composition progressively more negative and now compatible with the decomposition of organic materials in the prograding river delta. The isotopic composition of calcites in p6 drilling $\left(\delta^{13} \mathrm{C}\right.$ of $-12.2 \%$ and $\delta^{18} \mathrm{O}$ of $-9.1 \%$ o $)$ is a mixing between current calcite at Ponte Galeria area and $\mathrm{p} 1$ calcite levels, suggesting a significant contribution of organic $\mathrm{CO}_{2}$ in the peaty area where the old abandoned meander of the Tevere River is placed.

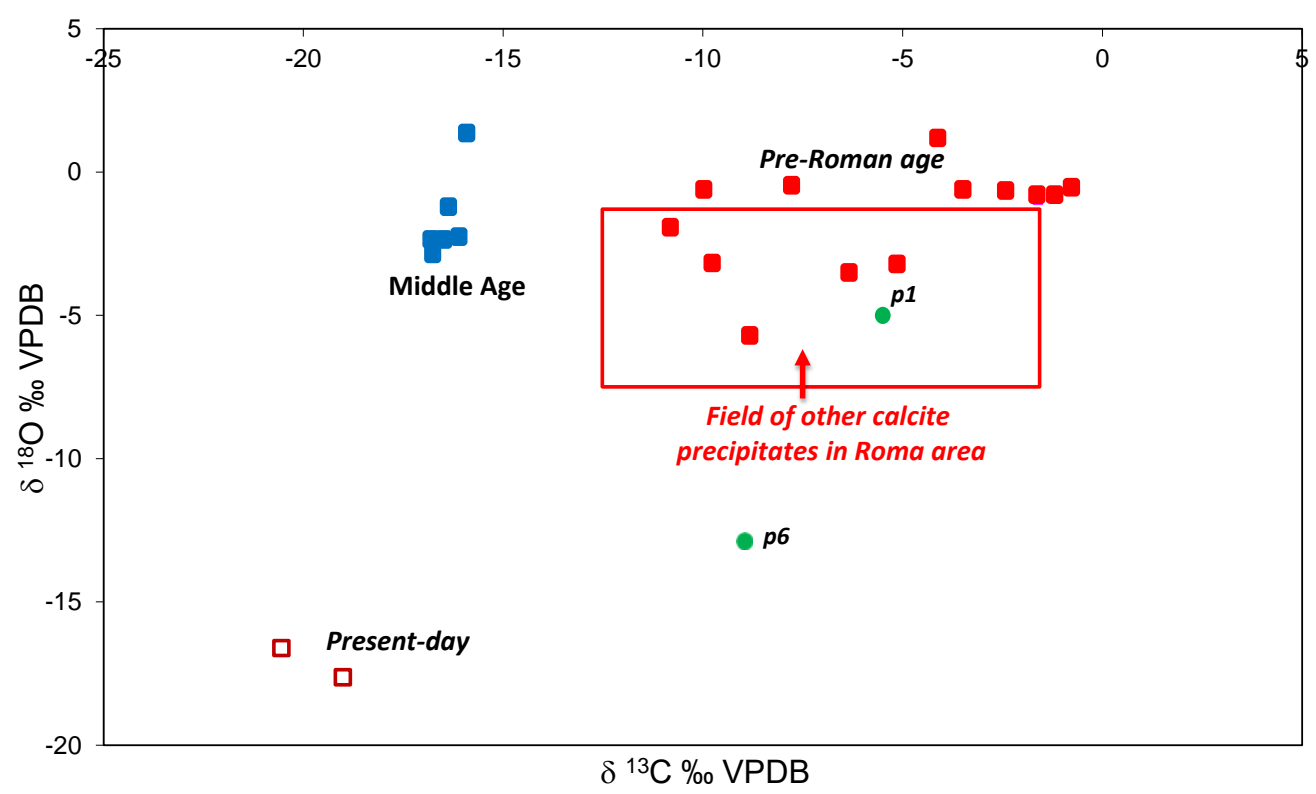

Figure 8. $\delta^{13} \mathrm{C}$ versus $\delta^{18} \mathrm{O}$ of calcite precipitates ( $\mathrm{p} 1$ and $\mathrm{p} 6$ ) in Ostia Antica stratigraphic sequence compared with other calcite in sediments, aqueducts, and caves of the Roma area (Italy). Squares represent calcites layers of different ages in the pre-Roman remains of the ancient Portuense road $([40,42,43]$ and Tuccimei, unpublished data).

The change in isotopic composition of Ponte Galeria calcites is in agreement with the TRD progradation in the last 2000 years and with the deposition of sediments rich in organic matter where decomposition phenomena produce carbon dioxide with a more negative signature. Calcite cements from p6 drilling at Ostia Antica archaeological park follow this environmental evolution, even if they are partly influenced by the deep $\mathrm{CO}_{2}$ upsurge. This isotopic composition (frankly, less negative) is dominant in p1 cements, located in proximity of a fault which borders the Primary Collector channel, where high concentrations of dissolved $\mathrm{CO}_{2}$ were reported [41]. This tectonic feature likely favors the rise of deep $\mathrm{CO}_{2}$, as in other areas of Roma [42], enhancing calcite deposition.

PCA analysis of the physicochemical data of groundwater $\left(\mathrm{HCO}_{3}, \mathrm{Cl}, \mathrm{SO}_{4}, \mathrm{Ca}, \mathrm{Mg}\right.$, $\mathrm{Na}, \mathrm{K}, \mathrm{Br}$, Water table elevation, $\mathrm{Br} / \mathrm{Cl}$, and $\mathrm{EC}$ ) supports the main results of our research. Only the Eigenvalues that have a value greater than 1 were arbitrarily selected as they are more significant and explain $76 \%$ of the total variance: respectively $60.27 \%$ and $15.67 \%$.

$\mathrm{PC} 1$ was mainly correlated positively to $\mathrm{EC}$, content of $\mathrm{Br}, \mathrm{Cl}, \mathrm{Mg}, \mathrm{Ca}$, and $\mathrm{SO}_{4}$ and $\mathrm{Br} / \mathrm{Cl}$ ratio, and negatively to groundwater level, while factor 2 has strong positive weighs on $\mathrm{K}$ and $\mathrm{HCO}_{3}-$, and less on $\mathrm{SO}_{4}$ and is negatively correlated to $\mathrm{Br} / \mathrm{Cl}$ ratio and content of $\mathrm{Ca}$ and $\mathrm{Cl}$. The coefficients of $\mathrm{PC} 1$ and PC2 for the 11 variables are reported in Table S4 (Supplementary Material). Accordingly, factor 1 accounts for freshwater-saltwater interactions, while factor 2 mostly reflects gas-water-rock interaction processes. The bi-plot of PC1 and PC2 (Figure 9) distinguishes the two circulations very well, evidencing the role of well $\mathrm{P} 1$ as the mixing point between the two circulations in the rainy period. 


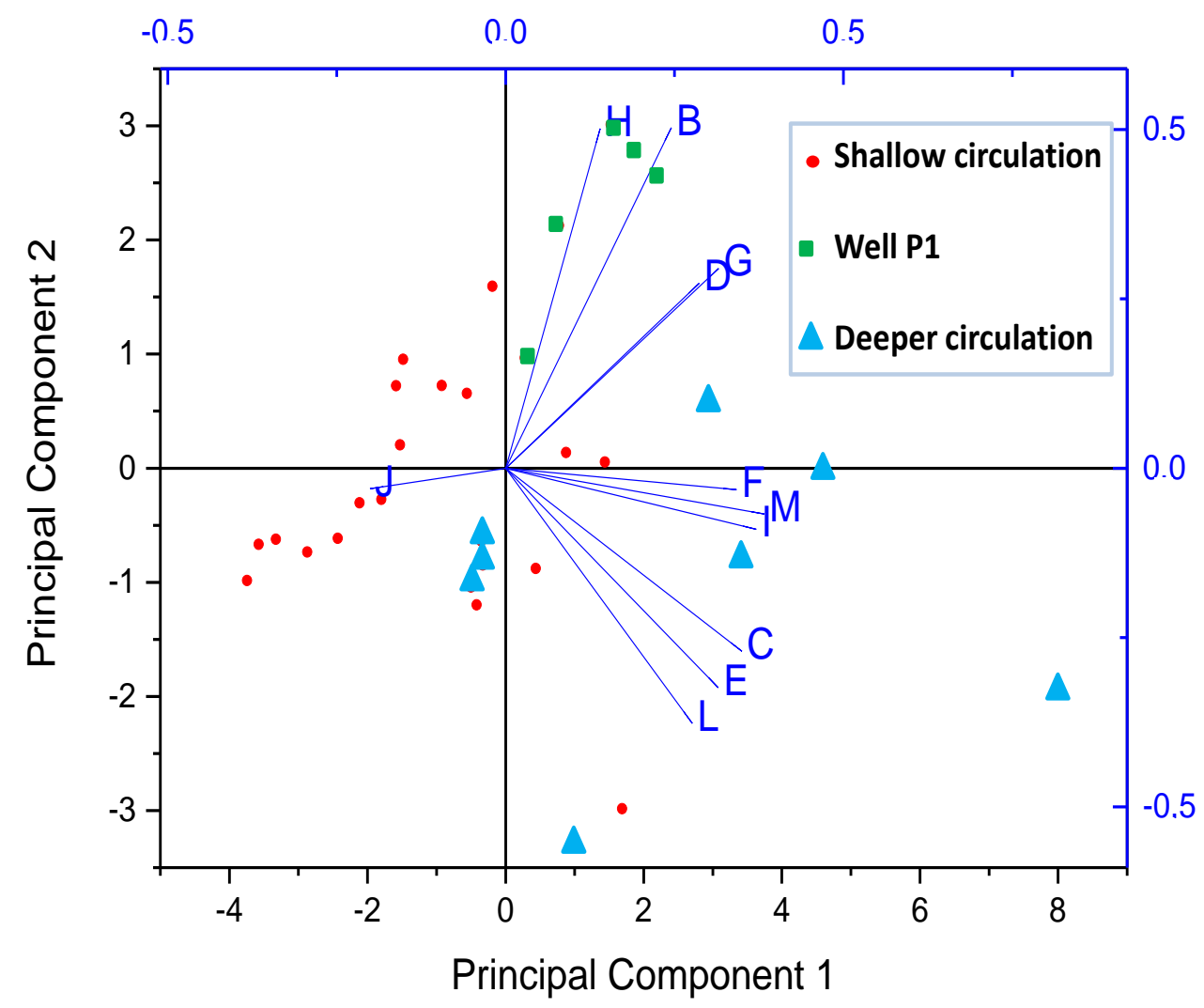

Figure 9. Bi-plot of principal components PC1 and PC2 of physicochemical data of groundwater in the area of Ostia Antica archaeological park. Eleven variables were selected: B. $\mathrm{HCO}_{3} ; \mathrm{C}$. Cl; D. SO E. Ca; F. Mg; G. Na; H. K; I. Br; J. Water table level; L. Br/Cl; M. EC. Shallow circulation is referred to wells P2, P3, P4, P8, P9, and P10; deeper circulation is linked to wells P6 and P7.

\section{Conclusions}

The purpose of this work was to study the processes of freshwater-saltwater interactions in a multilayer coastal aquifer (Ostia Antica archaeological park) using a hydrogeochemical approach.

Two different groundwater circulations were identified during the dry season, a shallower one in the archaeological park and a deeper one in the abandoned meander of Tevere River. The two circulations are separated by a partially impermeable sandy clay layer, intersected by the drillings from about -1.00 to $-1.40 \mathrm{~m}$ a.s.l. During the rainy season, the two circulations merge at well $\mathrm{P} 1$, but no further information is available for the nearby area. The recharge area of both circulations is located in the south-western sector of the study site, with a flow in WSW-ENE direction towards the Primary Collector channel.

This model of groundwater circulation was confirmed by hydrochemical data and PCA analysis. The upper circulation, typically alkaline-bicarbonate and calcium-bicarbonate, is characterized by moderately high EC values (about $850 \mu \mathrm{S} / \mathrm{cm}$ ) and relatively low chloride contents and $\mathrm{Cl} / \mathrm{Br}$ ratios attesting recharge inland. Negative $\mathrm{BEX}$ values strengthen the prevalence of freshening over salinization phenomena.

The deepest circulation hosted in the alluvial materials of the Tevere River is characterized by calcium chloride-sulphate and alkaline chloride-sulphate facies, with high average EC values (about $2600 \mu \mathrm{S} / \mathrm{cm}$ ). Chloride concentration and $\mathrm{Cl} / \mathrm{Br}$ ratios indicate that the sources of salinity are due to a local interaction of groundwater with the Roman salt pans and to agricultural practices. Positive values of BEX indices support the occurrence of salinization processes. Carbon and oxygen isotopic compositions point to a river delta environment where degradation of organic matters takes place releasing $\mathrm{CO}_{2}$ with a 
strong negative isotopic signature, very well matched with the nature of alluvial sediments hosting this circulation.

Hydrochemical data of well P1 demonstrate the mixing between the two circulations in the rainy period. Intermediate values of $\mathrm{EC}$, chlorides, and $\mathrm{Cl} / \mathrm{Br}$ ratios are in agreement with this scenario. Isotopic data are compatible with a circulation within the archaeological cover containing volcanic minerals and clearly record that calcite cements precipitated by groundwater rich in $\mathrm{CO}_{2}$ of deep provenance, likely rising along a fault that borders the Primary Collector channel. Finally, a salt-wedge intrusion along the Tevere River was demonstrated, especially during the spring and summer.

Supplementary Materials: The following are available online at https://www.mdpi.com/article/ 10.3390/w13131866/s1, Table S1: Temperature, Electrical Conductivity (EC), pH and water table elevation of groundwater, Table S2: Major ions and bromide concentration (meq/L) in groundwater of Ostia Antica archeological park. $\mathrm{Cl} / \mathrm{Br}$ ratio is expressed as molar ratio to fit Figure 7, modified from [30], Table S3: Average BEX of groundwater, sensu [27], sampled in the year 2016. Four groups of samples representing waters with homogenous and similar compositions were selected: the shallowest (wells P2, P3, P8, P9, and P10) and the deepest (wells P6 and P7) circulations, the Tevere River (P5), and well P1. The table also reports average saturation index (SI) for calcite, Table S4: Eigenvectors extracted from the correlation matrix of 11 physicochemical variables of groundwater. Data are available in Tables S1 and S2.

Author Contributions: Conceptualization, M.B., P.T., L.M. and R.M.; methodology, M.B., P.T., L.M. and R.M.; validation, M.B., P.T., L.M. and R.M.; writing—original draft preparation, M.B. and P.T. writing - review and editing, M.B., P.T., L.M. and R.M.; supervision, P.T., L.M. and R.M.; funding acquisition, R.M., P.T. and L.M. All authors have read and agreed to the published version of the manuscript.

Funding: This research was funded by Ministero dei Beni e delle Attività Culturali e del Turismo, Sovrintendenza Speciale per i Beni Archeologici di Roma. No Grant Number available. The grant to Department of Science, Roma Tre University (MIUR-Italy Dipartimento di Eccellenza, Articolo 1, Commi 314-337 Legge 232/2016) is also gratefully acknowledged.

Institutional Review Board Statement: Not applicable.

Informed Consent Statement: Informed consent was obtained from all subjects involved in the study.

Data Availability Statement: Data is contained within the article or supplementary material.

Acknowledgments: Authors wish to thank Renato Matteucci and Carlo Rosa for stimulating discussion. Moreover, special thanks to Carlo Rosa for providing us with the two-man auger Stihl BT 360 motor drill used for the three 3-5 m drillings.

Conflicts of Interest: The authors declare no conflict of interest.

\section{References}

1. Trabelsi, R.; Abid, K.; Zouari, K.; Yahyaoui, H. Groundwater salinization processes in shallow coastal aquifer of Djeffara plain of Medenine, Southeastern Tunisia. Environ. Earth Sci. 2002, 66, 641-653. [CrossRef]

2. Ahmed, M.; Samie, S.; Badawy, H. Factors controlling mechanisms of groundwater salinization and hydrogeochemical processes in the quaternary aquifer of the Eastern Nile Delta, Egypt. Environ. Earth Sci. 2013, 68, 69-394. [CrossRef]

3. Farid, I.; Trabelsi, R.; Zouari, K.; Abid, K.; Ayachi, M. Hydrogeochemical processes affecting groundwater in an irrigated land in Central Tunisia. Environ. Earth Sci. 2013, 68, 1215-1231. [CrossRef]

4. Tran, L.T.; Larsen, F.; Pham, N.Q.; Christiansen, A.V.; Nghi, T.; Vu, H.V.; Tran, L.V.; Hoang, H.V.; Hinsby, K. Origin and extent of fresh groundwater, salty paleowaters and recent saltwater intrusions in Red River flood plain aquifers, Vietnam. Hydrogeol. J. 2012, 20, 1295-1313. [CrossRef]

5. Bear, J.; Cheng, A.H.; Sorek, S.; Ouazar, D.; Herrera, D.H.I. Seawater Intrusion in Coastal Aquifers-Concepts, Methods and Practices; Kluwer Academic Publishers: Dordrecht, The Netherlands, 1999.

6. Meyer, R.; Engesgaard, P.; Sonnenborg, T.O. Origin and Dynamics of Saltwater Intrusion in a Regional Aquifer: Combining 3-D Saltwater Modeling with Geophysical and Geochemical Data. Water Resour. Res. 2019, 55, 1792-1813. [CrossRef]

7. Mahesha, A.; Nagaraja, S.H. Effect of natural recharge on sea water intrusion in coastal aquifers. J. Hydrol. 1996, 174, 211-220. [CrossRef] 
8. Custodio, E.; Llamas, M.R. Rapporti tra le acque dolci e salate nelle regioni costiere. In Idrologia Sotterranea; Dario Flaccovio: Palermo, Italy, 2005; Volume 2, pp. 1248-1274.

9. Narayan, K.A.; Schleeberger, C.C.; Bristow, K.L. Modelling seawater intrusion in the Burdekin Delta Irrigation Area, North Queensland, Australia. Agric. Water Manag. 2007, 89, 217-228. [CrossRef]

10. Park, S.C.; Yun, S.; Chae, G.T.; Yoo, I.S.; Shin, K.S.; Heo, C.H.; Lee, S.K. Regional hydrochemical study on salinization of coastal aquifers, western coastal area of Korea. J. Hydrol. 2005, 313, 182-194. [CrossRef]

11. Mastrocicco, M.; Colombani, N. The Issue of Groundwater Salinization in Coastal Areas of the Mediterranean Region: A Review. Water 2021, 13, 90. [CrossRef]

12. Langevin, C.; Sanford, W.; Polemio, M.; Povinec, P. Background and summary. A new focus on groundwater-seawater interations. Proceedings of Symposium HS1001 at IUGG2007, Perugia, Italy, 10 July 2007. IAHS Publ. 2007, 312, 3-10.

13. Gustafson, C.; Key, K.; Evans, R.L. Aquifer systems extending far offshore on the U.S. Atlantic margin. Sci. Rep. 2019, 9, 8709. [CrossRef]

14. Micallef, A.; Person, M.; Haroon, A.; Weymer, B.A.; Jegen, M.; Schwalenberg, K.; Faghih, Z.; Duan, S.; Cohen, D.; Mountjoy, J.J.; et al. 3D characterisation and quantification of an offshore freshened groundwater system in the Canterbury Bight. Nat. Commun. 2020, 11, 1372. [CrossRef] [PubMed]

15. Idczak, J.; Brodecka-Goluch, A.; Lukawska-Matuszewska, K.; Graca, B.; Gorska, N.; Klusek, Z.; Pezacki, P.D.; Bolałek, J. A geophysical, geochemical and microbiological study of a newly discovered pockmark with active gas seepage and submarine groundwater discharge (MET1-BH, central Gulf of Gdansk, southern Baltic Sea). Sci. Total Environ. 2020, 742, 140306. [CrossRef]

16. Jakobsson, M.; O’Regan, M.; Morth, C.M.; Stranne, C.; Weidner, E.; Hansson, J.; Gyllencreutz, R.; Humborg, C.; Elfwing, T.; Norkko, A.; et al. Potential links between Baltic Sea submarine terraces and groundwater seeping. Earth Surf. Dyn. 2020, 8, 1-15. [CrossRef]

17. Pydyn, A.; Popek, M.; Kubacka, M.; Janowski, Ł. Exploration and reconstruction of a medieval harbour using hydroacoustics, 3-D shallow seismic and underwater photogrammetry: A case study from Puck, southern Baltic Sea. Archaeol. Prospect. 2021. [CrossRef]

18. Finetti, I.R. The CROP profiles across the Mediterranean Sea (CROP MARE I and II). Mem. Descr. Carta Geol. It. 2003, 62, 171-184.

19. Bellotti, P.; Davoli, L.; Terragoni, C. L'evoluzione del litorale tiberino negli ultimi 3000 anni sotto le forzanti naturali e antropiche. Stud. Costieri 2014, 22, 33-43.

20. EASAC-European Academies Science Advisory Council. Groundwater in the Southern Member States of the European Union: An Assessment of Current Knowledge and Future Prospects; German Academy of Sciences Leopoldina: Halle, Germany, 2010.

21. Mastrorillo, L.; Mazza, R.; Manca, F.; Tuccimei, P. Evidences of different salinization sources in the roman coastal aquifer (Central Italy). J. Coast. Conserv. 2016, 20, 423-441. [CrossRef]

22. Capelli, G.; Mazza, R.; Papiccio, C. Saline intrusion in the Tiber Delta Geology, hydrology and hydrogeology of the coastal plain of the roman sector. Giorn. Geol. Appl. 2007, 5, 13-28.

23. Manca, F.; Capelli, G.; La Vigna, F.; Mazza, R.; Pascarella, A. Wind-induced salt-wedge intrusion in the Tiber river mouth (Rome-Central Italy). Environ. Earth Sci. 2014, 72, 1083-1095. [CrossRef]

24. Tuccimei, P.; D’Angelantonio, M.; Manetti, M.C.; Cutini, A.; Amorini, E.; Capelli, G. The chemistry of precipitation and groundwater in a coastal Pinus Pinea forest (Castel Fusano area, Central Italy) and its relation to stand and canopy structure. In Horizons in Earth Science Research; Szigethy, B.V., Ed.; Nova Science Publishers, Inc.: Suite N Hauppauge, NY, USA, 2011; Volume 4, pp. 1-17.

25. Manca, F.; Capelli, G.; Tuccimei, P. Sea salt aerosol groundwater salinization in the Litorale Romano Natural Reserve (Rome, Central Italy). Environ. Earth Sci. 2015, 73, 4179-4190. [CrossRef]

26. Goiran, J.P.; Salomon, F.; Mazzini, I.; Bravard, J.P.; Pleuger, E.; Vittori, C.; Boetto, G.; Christiansen, J.; Arnaud, P.; Pellegrino, A.; et al. Geoarcheology confirms location of the ancient harbour basin of Ostia (Italy). J. Archaeol. Sci. 2013, 41, 89-398.

27. Aeronautica Militare-Servizio Meteorologico. Atlante Climatico d'Italia 1971-2000; Centro Nazionale di Meteorologia e climatologia aereonautica; Pratica di Mare: Rome, Italy, 2009; Volume 3.

28. Bellotti, P.; Chiocci, F.L.; Milli, S.; Tortora, P.; Valeri, P. Sequence stratigraphy and depositional setting of the Tiber delta: Integration of high-resolution seismics, well logs, and archeological data. J. Sediment Res. Sect. Stratigr. Glob. Stud. 1994, 64, 416-432.

29. Funiciello, R.; Giordano, G.; Mattei, M. Carta Geologica del Comune di Roma Scala 1:50.000; S.EL.CA.: Firenze, Italy, 2008.

30. Mazza, R.; La Vigna, F.; Capelli, G.; Dimasi, M.; Mancini, M.; Mastrorillo, L. Idrogeologia del territorio di Roma. Acque Sotter. It. J. Groundw. 2016, 4, 19-30.

31. Mastrorillo, L.; Mazza, R.; Tuccimei, P.; Rosa, C.; Matteucci, R. Groundwater monitoring in the archaeological site of Ostia Antica (Rome, Italy): First results. Acque Sotter. It. J. Groundw. 2016, 5, 35-42. [CrossRef]

32. Mastrorillo, L.; Mazza, R.; Viaroli, S. Recharge process of a dune aquifer (Roman coast, Italy). Acque Sotter. It. J. Groundw. 2018, 356, 6-19. [CrossRef]

33. Petitta, M.; Primavera, P.; Tuccimei, P.; Aravena., R. Interaction between deep and shallow groundwater systems in areas affected by Quaternary tectonics (Central Italy): A geochemical and isotope approach. Environ. Earth Sci. 2011, 63, 11-30. [CrossRef]

34. Packhurst, D.L.; Appelo, C.A.J. Description of input and examples for PHREEQC version 3. A computer program for speciation, batch-reaction, one-dimensional transport, and inverse geochemical calculations. In Department of the Interrior U.S. Geological Survey, Groundwater Book 6, Modeling Techniques; A43 US: Denver, CO, USA, 2013; Volume 43. 
35. Schoeller, H. Les échanges de base dans les eaux souterraines; trois exemples en Tunisie. Bull. Soc. Geol. Fr. 1934, 4, 389-420.

36. Brilli, M.; Giustini, F.; Kadioglu, M. Black limestone used in antiquity: Recognizing the limestone of Teos. Archaeometry 2019, 61, 282-295. [CrossRef]

37. Gaeta, M.; Freda, C.; Christensen, J.N.; Dallai, L.; Marra, F.; Karner, D.B.; Scarlato, P. Time-dependent geochemistry of clinopyroxene from the Alban Hills (Central Italy): Clues to the source and evolution of ultrapotassic magmas. Lithos 2006, 86, 330-346. [CrossRef]

38. Sánchez-Martos, F.; Pulido-Bosch, A.; Molina-Sánchez, L.; Vallejos-Izquierdo, A. Identification of the origin of salinization in groundwater using minor ions (Lower Andarax, Southeast Spain). Sci. Total Environ. 2002, 297, 43-58. [CrossRef]

39. Naily, W.; Naily, S. Cl/Br Ratio to Determine Groundwater Quality. In Proceedings of the IOP Conference Series: Earth and Environmental Science, Yogyakarta, Indonesia, 20-24 August 2018.

40. Tuccimei, P.; Soligo, M.; Arnoldus-Huyzendveld, A.; Morelli, C.; Carbonara, A.; Tedeschi, M.; Giordano, G. Datazione U/Th di Depositi Carbonatici Intercalati ai Resti della Via Portuense Antica (Ponte Galeria, Roma): Attribuzione Storico-Archeologica della Strada e Documentazione Cronologica Dell'attività Idrotermale del Fondovalle Tiberino. Available online: www.fastionline. docs/FOLDER-it-2007-97.pdf (accessed on 12 December 2007).

41. Ciotoli, G.; Etiope, G.; Marra, F.; Florindo, F.; Giraudi, C.; Ruggiero, L. Tiber Delta $\mathrm{CO}_{2}-\mathrm{CH}_{4}$ degassing: A possible hybrid, tectonically active Sediment-Hosted Geothermal System near Rome. J Geophys. Res. Solid Earth 2015, 121, 48-69. [CrossRef]

42. Tuccimei, P.; Giordano, G.; Tedeschi, M. CO 2 release variations during the last 2000 years at the Colli Albani volcano (Roma, Italy) from speleothems studies. Earth Planet. Sci. Lett. 2006, 243, 449-462. [CrossRef]

43. Rustico, L.; Buonfiglio, M.; Zanzi, G.L.; Brilli, M.; Soligo, M.; Tuccimei, P. Relazioni su scavi, trovamenti, restauri in Roma e Suburbio 2017-2019. Regione XII. Viale Guido Baccelli, largo Enzo Fioritto, viale Giotto. Rinvenimento di una diramazione dell'Acquedotto Antoniniano. Bull. Comm. Archeol. Comunale Roma 2019, 120, 359-364. 